\title{
Construction of Natures and Protests on Instagram: A Study of Virtual Environmental Activism in India During the COVID-19 Pandemic
}

NIVEDITA TULI, Independent Researcher AZAM DANISH, Independent Researcher

\begin{abstract}
In 2020, the COVID-19 pandemic and lockdown in India restricted 'real world' protests, shifting dissent to digital spaces. In this article we explore virtual environmental activism on Instagram by looking at two case-studies that gained prominence during this period. The first was the death of a pregnant elephant in Kerala by consuming cracker-laden food meant to deter boars from cropraiding. The second was an oil and gas leak in Baghjan, an ecologically sensitive region in Assam. Through content analysis of 'Top' posts, we thematically classified the representations of nature and non-humans constructed through Instagram visuals, identifying overlaps and contradictions in the two cases. Observing that the images of animals in pain generated massive response, we argue that Susan Sontag's (2003) framework on the haunting power of images of human suffering can be expanded to include non-humans. These visuals highlight certain creatures, excluding other species and vilifying human communities belonging to the same landscapes. We show how unilinear models of economic development and progress, as well as hierarchical and casteist notions in Hinduism continue to shape environmental debates in India. The religious overtones discount the environmental discourse based on scientific knowledge, and disrupt nuances of community driven action. By tracing the online trajectories of the two protests, we also illustrate how virality limits Instagram activism by sidelining local voices and privileging short-lived consumer action over systemic change.
\end{abstract}

\section{KEYWORDS}

COVID-19, Environmental Activism, Non-Humans, Instagram, India

\section{Introduction}

The SARS-CoV-2 virus left no country untouched in 2020, but the lived reality of the COVID-19 pandemic varied across the world. India's pandemic experience was shaped by the ruling Hindu nationalist Bhartiya Janata Party (BJP), but also had roots in the country's colonial past. On 24 March 2020, almost two months after the first case of COVID-19 was reported in India, Prime Minister Narendra Modi announced that the country of 1.38 billion people would be placed under complete lockdown starting midnight. The initial twenty-one day lockdown was extended thrice, with the unlock process beginning in June (Sharma 2020). Road, railway and air transport services were suspended, except for the carriage of essential commodities and movement of the police and healthcare workers (Hebbar 2020). The brunt of this hastily-imposed lockdown fell disproportionately on the country's poorest and most vulnerable. Millions of migrant workers were 
stranded in cities and had to walk hundreds of kilometres to reach their villages and hometowns (Shroff 2020). The timing of the pandemic was fortuitous for the ruling party, which had been facing nationwide protests against its Islamophobic and anti-poor policies such as the Citizenship (Amendment) Act 2019, proposed National Register of Citizens, and the Draft Environmental Impact Assessment Notification 2020. In the shadow of the pandemic, protest sites were dismantled, and journalists, activists, and academics critical of the government were incarcerated. The BJP legitimised its actions by invoking the Epidemic Diseases Act 1897, a draconian colonialera law drafted by the British government during the plague pandemic of the late nineteenth century (Banerjee 2020). The lockdown also enabled the state to strengthen online surveillance personal data of fifty million people was collected in government servers through the Aarogya Setu mobile application meant to track coronavirus cases (Freedom House 2020).

The lockdown was enforced through violence - in many Indian states, people spotted on the streets were assaulted and imprisoned by the police, even if they were seeking essential supplies (Human Rights Watch 2021). Barred from mobilising outdoors, those who could began to convene virtually (note that only 24\% of Indian households have internet access) (UNICEF 2020). Several existing protests shifted to digital spaces, and protestors also came together against new policies and incidents online. The protests manifested on social media websites which are extremely popular in India - there are over four hundred million social media users, with Facebook leading in user count, followed by YouTube and Instagram (Keelery 2020). In this article, we examine virtual protests on Instagram during the COVID-19 lockdown. In particular we explore environmental protests and attempt to understand the ways in which these construct ideas of nature on Instagram. In post-COVID times, it is especially important to study virtual manifestations of nature, since the pandemic has limited people's access to landscapes and creatures in the 'real world'. Nature itself is a value-laden term, and scholars have critiqued dominant discourses that posit nature as separate from culture and non-humans in opposition to humans (see Latour 1993; Cronon 1996). These dualisms are also hierarchical; non-humans and nature are seen as inferior to humans and culture. This article is an investigation of popular social media narratives of nature and creatures. By studying and questioning these narratives which traverse our daily lives, we reflect on their implications for the relationship between humans and non-humans.

\section{Review of Literature}

\subsection{Activism on Social Media}

In the early years of social media, Clay Shirky (2008) predicted that social media sites would enable group action in a manner that could earlier be accomplished only through institutions. Paolo Gerbaudo (2012) contended that social media had the potential to create a virtual public sphere where previously fragmented groups could assemble. The idea of social media as a new public sphere was taken forward by Payal Arora (2014), who drew parallels between public parks and social media platforms, noting that while both had been designed for leisure, they often morphed into sites of resistance. Evgeny Morozov (2009) on the other hand, maintained that social media 
generates a kind of lazy, pseudo-activism or 'slacktivism', where liking and sharing posts becomes a substitute for meaningful yet exhausting, real-world action. Vincent Miller (2017) argued that social media does not foster meaningful political debate, but rather serves a 'phatic' function, enabling people to maintain existing ties and validate others with the same opinions. While Morozov and Miller posit social media as opposed to traditional activism, other studies illustrate how it has supplemented real-world protests through mobilisation and fundraising (see Fischer 2015; Lovejoy and Saxton 2012).

It has been observed that social media has a high affinity for populism. Gerbaudo (2018) identifies two reasons for this. First, social media is often perceived as an alternative to mainstream media, which is seen as suspicious and controlled by big businesses and political parties. This view overlooks the fact that social media platforms are themselves run by large corporations such as Facebook and Google. Second, the architecture of social media is built to aggregate. It brings together isolated individuals with common interests, generating online 'crowds' which have the potential to transform into mobs. It is also relevant to look at how states engage with social media activism. Thomas Poell (2014) illustrates how state censorship shapes protests on social media using case-studies from China and Iran. Activists have used anonymous accounts and misspell words to prevent detection, however, the effectiveness of such techniques is limited. Social media sites are constructed in a manner that curbs protest activity - accounts often mandate real names, content can be removed if reported, and frequent changes to the platforms prevents activists from devising ways to be discreet. Poell suggests using a combination of social media platforms to safeguard online protests.

\subsection{Instagram as a Medium for Research}

Instagram was launched in 2010 as an image sharing mobile application. Ten years and a billion users later, it remains a phone-based platform - while posts and stories can be viewed on the Instagram website, new content can be uploaded only through phones (Caliandro and Graham 2020). Unlike Facebook and Twitter, where images and videos are optional accompaniments to text, Instagram mandates the use of visuals. This makes it a valuable source of digital photographs which can be examined using existing theoretical frameworks on photography. Digital images also hold political power, providing evidence and context for real world protests, and even themselves become safe sites of protests for vulnerable groups like women, or during crises like the COVID19 pandemic (Highfield and Leaver 2016). Instagram is also known for its dynamicity. Several new features have been added since 2010, including hashtags in 2011, videos in 2013, stories and live videos in 2016, IGTV in 2018, and reels in 2020 ('Timeline of Instagram' 2020). The platform is also distinctive for research because of its young user base, with $60 \%$ of its users aged between 18 and 34 (Clement 2020).

The basic unit of Instagram research is the hashtag. A hashtag is a metadata tag created by adding a '\#' symbol before a word or unspaced phrase. Users can click on a hashtag to reach all the content labeled using the same tag (Veszelszki 2016). Stamatios Giannoulakis and Nicolas Tsapatsoulis 
(2016) established that Instagram hashtags can be used to train image annotation software since they more accurately describe photographs compared to other methods like crowdsourcing. Hashtags do not simply serve a descriptive purpose; they may be used to increase the visibility of posts ('like-hunter' tags), to showcase capital, or to express a mood or feeling (Veszelszki 2016). Employing the hashtag as a basic unit, Instagram has been used for research on various themes. Many scholars have studied self-representation on Instagram, particularly through 'selfies' (selfportraits using phones' front cameras) (see Souza et al. 2015; Wagner, Aguirre Alfaro and Bryant 2016; Caldeira, De Ridder and Van Bauwel 2020). The agenda-setting role of Instagram has also been examined. Terri Towner and Caroline Lego Muñoz (2020) discussed the disparity between the salient issues on Instagram and mainstream media during the 2016 United States presidential elections. Luis Casaló, Carlos Flavián and Sergio Ibáñez-Sánchez (2018) observed the phenomenon of opinion-leaders or 'influencers' on Instagram, and their role in shaping followers' consumption patterns. Existing literature explores the implications of Instagram use on mental health (Frison and Eggermont 2017), and Instagram posts have also been used to study bullying, depression and eating disorders. A model for predicting suicidality using Instagram data has also been proposed (Brown et al. 2019). John D. Boy and Justus Uitermark (2016) have developed novel methods for urban studies using Instagram's geo-tagging feature, Jeffrey P. Carpenter et al. (2020) examined the use of Instagram by educators, while Elisa Serafinelli (2020) studied how Instagram photographs retain traditional photography's purpose of memory preservation.

\subsection{Digital Representations of Nature}

In The Society of the Spectacle (1967), philosopher Guy Debord contended that in modern society, everything that was earlier experienced personally has been replaced by its representation. 'The spectacle' refers to social relations among people, which are now mediated through images. Using Debord's framework of the spectacle, Jim Igoe (2010) examined media representations of nature, and problematised images circulated by conservation organisations. He used the Maasai Steppe Heartland of Tanzania as a case-study to illustrate how indigenous communities and their landscapes are commodified by conservation organisations competing for funding. Images of the Maasai circulated by the African Wildlife Foundation portray their lives as noble, their environment as pristine, and their relationship with non-humans as entirely peaceful. The images ignore the historical processes underlying the Maasai's marginalisation, hide the human-wildlife conflicts that have forced tribespeople to relocate, and invisiblise other communities and their struggles. The visually-mediated relationship between donors and conservation organisations is based on promises of redemption and repair. This guise of redemption creates opportunities for capitalist expansion and is disconnected from reality. The visually-mediated spectacle serves as a fleeting moment of participation and leads to downplaying of structural imbalances (Büscher and Igoe 2013).

While Igoe looked at media images in general, Bram Büscher (2016) studied representations of nature on the Internet in particular, arguing that there exists a 'second nature' or 'Nature 2.0' which is co-created by conservation organisations and ordinary people on the Internet, on eco-search 
engines, conservation-themed games, communities geared towards conservation, citizen science mobile apps, etc. In Nature 2.0, real landscapes and creatures are portrayed in a romantic, exaggerated manner to gather more clicks and donations, commodifying them in the process. Michael K. Goodman et al. (2016) have pointed out that online campaigns urging individuals to support and fund conservation efforts individualise responses at a time when collective action is needed.

In another important work, Crystal Abidin et al. (2020) identified various tropes of celebrity environmentalism. They observed that celebrities have a specific form of capital (deriving from Pierre Bourdieu's (1993) field theory) which gives them recognisability and influence across multiple platforms. However, celebrity activism legitimises ways of thinking about issues and solutions which are far from socio-ecological lived realities, and push for consumer action instead of systemic overhaul. David W. MacDonald et al. (2016) examined social media response in the case of 'Cecil the Lion' who was hunted in Zimbabwe in 2015. In this case of trophy hunting, there was a quick and furious social media response across the world, especially in the Global North. But after the initial furore died out, the incident was all but forgotten. MacDonald et al. ask, was the response a 'movement' or a mere 'viral moment'? They suggest that Cecil became a spectacle - his hunting ignited emotive response, which was rather long-lived for a social media movement but too short-lived for any structural changes to take place.

According to Trevor Garrison Smith (2017) technology is not an obstacle for demonstration of protests; the impediments are political in nature. He argues that the economic rationalities of neoliberalism have led to a loss of political avenues, and people want alternatives to the antipolitical status quo. For Smith, the Internet is necessary for the revival of politics due to its potential to bring forth alternative voices and create novel tools for engagement and collective action. He explores the intricacies of the Internet and the ways in which political engagements can take place on multiple terrains, as imagined by Hannah Arendt (2005). Engagement with political practices in daily lives in our homes, offices and while traveling is an interesting prospect, and Smith believes it has radical potential.

\subsection{India's Digital Mediascape}

India is a multi-religious, multilingual, and multi-ethnic country with shared, yet contested histories. In recent years, these contestations have acquired new forms and manifested in new spaces. Since 2013, digital spaces have increasingly been flooded by Hindu nationalist rhetoric by the ruling BJP (Rodrigues and Niemann 2017). BJP's Information Technology (IT) cell is not only used for political campaigning, but also for spreading narratives that glorify Hindu rulers and vilify Islamic dynasties of the past, intimidating journalists, scholars and anti-establishment organisations, and running smear campaigns to discredit mainstream news and protests against government policies (Chaturvedi 2016). Sahana Udupa (2016) has argued that the work of BJP's IT cell constitutes a distinct politics of history-making - online archiving. 'Online archiving' is the practice of presenting facts, figures and treatises as an ideological exercise by non-experts (Udupa 
2016). Udupa has illustrated the role of social capital in online archiving, noting that volunteers belong to privileged sections of society and find a newfound sense of political agency on social media. This practice is aimed at producing a homogenous Hindu nation by attacking plural and secular historical narratives, and offers a troubling picture of India's digital commons (Udupa 2016). Prashanth Bhat and Kalyani Chadha (2020) have identified specific discursive strategies employed by right-wing online platforms for the systemic discrediting of the mainstream press. Articles on websites such as OpIndia.com narrativise established media organisations as 'antiHindu' or 'anti-national', and effort is made to bring 'Hindu issues' to the fore.

India's digital infrastructure has been shaped by both its colonial history and contemporary rules of inclusion and exclusion. Western frameworks cannot be applied generally in the South Asian context because of the colonial history of information infrastructures, communal and caste politics, and a 'development legacy' of welfare schemes tied to specific political groups (Arora 2019). The disputed state of Kashmir was disconnected from global internet and mobile infrastructures for months after the controversial abrogation of Article 370 by the Indian government (Punathambekar and Mohan 2019). As the disparity in digital infrastructure widened, the social media presence of Kashmir's social and political groups diminished. Meanwhile, the cyber volunteers of the ruling party justified the actions, citing the threat of terrorism and radicalisation. It is imperative to historicise the current media paradigm in India, to examine the underlying politics and rules of access. Arora (2019) and Usha M. Rodrigues and Michael Niemann (2017) have suggested the need for an integrated examination into the phenomenon, especially due to the resurfacing of exclusionary, communal and casteist political discourse.

Spiritual ecology is a conceptual framework used to understand how religious and spiritual values shape attitudes towards nature and environmentalism. Kelly Alley (2019) has examined legal cases which designated the Indian rivers Ganga and Yamuna as legal persons. Alley argues that the identification of sacred rivers as human influences legal interventions and enforcement powers, and such personification of nature reinforces 'soft Hindutva' in the garb of spiritual ecology. Eliza Kent (2015) and Owen Ellerkamp (2018) have examined the particularities of Indian environmentalism and discussed how religion has been used to promote pro-environment action and even been considerably successful in mobilising people. Ellerkamp (2018) contends that the rise of the BJP and its brand of environmentalism has been employed to prioritise geographical features tied to imagined Hindu pasts and futures furthering the Hindu nationalist agenda. Such environmentalism is problematic because it is not based on ecological concerns, but rather on ideas of Hindu nationalist and cultural supremacy. Hindutva environmentalism also overshadows scientific sensibilities which would be more effective and less divisive.

\subsection{Understandings of Environmental Justice}

Does the phrase 'environmental justice' have a fixed connotation across time and space? Or do discourses around environmental justice function according to strategic selection? The most influential justice theorists of the twentieth century (such as John Rawls and Ronald Dworkin) 
understood justice as a question of equity in the distribution of goods, political, social and economic. The idea of 'justice as distribution' dominated academic discourse for decades, and the first generation of environmental justice research was conducted within the same frame. Most of these early studies mapped the spatial distribution of 'environmental goods' (such as urban green spaces) and 'environmental bads' (waste, landfill and industrial sites or sites vulnerable to natural disasters) and examined their proximity to marginalised groups in society (Greenberg 1993; Grossman 1991).

David Scholsberg (2004) suggested that the understanding of justice as distribution is insufficient in praxis. He pointed at the various demands for justice by media, individuals, and civil society organisations for a comprehensive approach and indicated the need to study discourses which challenge existing academic understanding of environmental justice. Gordon Walker (2009b) argued that it is of utmost importance to recontextualise matters of environmental justice. He emphasised the significance of geography and the need for non-universal and non-technocratic approaches. Another important element of environmental justice is participation. It has been argued that when decisions regarding the utilisation of a particular habitat need to be made, those who will be most affected by the change must have the right to be involved in the decision-making process (Schlosberg 2009).

Anna Stanley (2009) presented another strong case against distributive concepts of justice and argued for critical engagement with the politics that structure environmental practices. She contended that the distributive understanding views spatial and human relationships as nondynamic, depoliticised and bourgeois, and doesn't question the privilege linked with such a position. Stanley suggested that depoliticised analysis of injustice reproduced hegemonic social structures and patterns of oppressions. Drawing from feminist critiques of distributive justice, she argued that difference and difference-making must be acknowledged and should not be confused with liberal subjectivities which universalise exploitative spatial and human relationships. She demonstrated that spatial processes are constructed due to difference, and space is central to relationships and discourses and it is necessary to politicise sites of environmental practice and difference making.

\section{Methodology}

To study representations of nature on Instagram, we selected two case-studies from India which gained prominence during the COVID-19 lockdown. The first was the death of a pregnant elephant in South India after ingesting crackers meant to drive away boars from farmland. The second was an oil and gas leak in the Baghjan oil field, located in an ecologically fragile region in northeast India. These case-studies were chosen because we observed that Instagram posts on these events seemed to highlight opposing notions of the relationship between humans and non-humans. In the Baghjan case, the OIL corporation was criticised for causing the dual destruction of wildlife habitats and human livelihoods, while in the elephant case, human livelihoods were seen as antagonistic to non-human creatures. 
To understand how the case-studies were portrayed on Instagram, we began by identifying the most popular hashtags for both cases. Next, six hashtags were selected (three for each event) which were uniquely used for posts on these cases (see Table 1). Instagram has a 'Top' posts section which features the most popular posts for each hashtag, determined by the posts' 'engagement' and the speed at which it is attained. Engagement is a measure of the likes, views, comments and number of saves a post receives on Instagram (Finley 2020). We used a content scraper built on Python to extract one hundred 'Top' posts for six hashtags dating up to 31 October 2020. The visuals, date of posting, name of account, captions, number of likes and number of comments were also collected. We undertook a thematic classification of the posts using content analysis, which we present in the following section.

We also sought to visualise the life-cycles of these case-studies on Instagram. For this we created scatter-plots, plotting dates on the $\mathrm{X}$-axis and number of posts on the $\mathrm{Y}$-axis. The objective here was to understand whether these events were sustained protests with long-term goals and realworld results, or simply ephemeral 'moments' that commenced and concluded with little impact.

Table 1. Hashtags used on Instagram for case-studies.

\begin{tabular}{|c|c|c|}
\hline CASE-STUDY & MOST POPULAR HASHTAGS & $\begin{array}{c}\text { HASHTAGS FOR CONTENT } \\
\text { ANALYSIS }\end{array}$ \\
\hline $\begin{array}{l}\text { Kerala Elephant } \\
\text { Death }\end{array}$ & $\begin{array}{l}\text { \#animalcruelty, \#elephantdeath, } \\
\text { \#justiceforelephant, } \\
\text { \#justiceforvinayaki, \#keralaelephant, } \\
\text { \#keralaelephantmurder, \#ripelephant, } \\
\text { \#riphumanity }\end{array}$ & $\begin{array}{l}\text { \#justiceforelephant, } \\
\text { \#justiceforvinayaki, } \\
\text { \#keralaelephantmurder }\end{array}$ \\
\hline $\begin{array}{l}\text { Baghjan Oil and } \\
\text { Gas Leak }\end{array}$ & $\begin{array}{l}\text { \#baghjan, \#baghjanfire, } \\
\text { \#baghjanoilfield, \#baghjanburning, } \\
\text { \#oilindialimited, \#saveassam, } \\
\text { \#savebaghjan, \#savemaguribeel, } \\
\text { \#savedibrusaikhowa, \#saveriverdolphin }\end{array}$ & $\begin{array}{l}\text { \#baghjan, \#baghjanoilfield, } \\
\text { \#savebaghjan }\end{array}$ \\
\hline
\end{tabular}

\section{Findings}

\subsection{Case-study 1: Kerala Elephant}

\subsubsection{Background}

On 27 May 2020, Kerala-based forest officer Mohan Krishnan posted images of a dying female elephant on Facebook. Krishnan's grieving post attributed the elephant's death to the ingestion of 
firecrackers, but he also claimed that the creature had performed jala samadhi, a ritual in Hindu mythology through which Lord Rama had passed on from the world (Krishnan 2020). The incident gained enormous attention on social media. The post-mortem confirmed the cause of death to be the ingestion of a pineapple stuffed with firecrackers, and revealed that the elephant had been pregnant. Maneka Gandhi, BJP politician and animal rights activist, demanded punishment for the elephant's 'murderers', claiming that they belonged to the Muslim majority 'criminally active' Malappuram district of Kerala (Gandhi 2020). Later investigations revealed that the elephant had died in the Hindu majority Palakkad district. It was also found that local farmers had planted the firecrackers to deter boars from crop raiding (Nishant 2020).

\subsubsection{Thematic Classification}

Through our content analysis of three hundred 'Top' posts on Instagram tagged \#keralaelephantmurder, \#justiceforelephant, and \#justiceforvinayaki, we identified the eight themes discussed below. Multiple themes often overlap in posts.

Table 2: Themes identified in posts on the Kerala Elephant case.

\begin{tabular}{|c|c|}
\hline THEMES & OVERVIEW \\
\hline 1. Vilification of Humans & Portrayal of humans as barbarians and non-humans as victims. \\
\hline $\begin{array}{l}\text { 2. Non-human Animals in } \\
\text { Hinduism }\end{array}$ & $\begin{array}{l}\text { Connections drawn between the elephant's death and } \\
\text { narratives from Hindu mythology. }\end{array}$ \\
\hline 3. Glorification of Motherhood & $\begin{array}{l}\text { Highlighting the elephant's pregnancy, anthropomorphisation, } \\
\text { idealising motherhood. }\end{array}$ \\
\hline 4. Diets and Animal Rights & $\begin{array}{l}\text { Promotion of veganism and vegetarianism, criticism of meat- } \\
\text { eaters. }\end{array}$ \\
\hline $\begin{array}{l}\text { 5. Appropriation of Black Lives } \\
\text { Matter }\end{array}$ & $\begin{array}{l}\text { Black Lives Matter movement appropriated to gain visibility; } \\
\text { historical content ignored. }\end{array}$ \\
\hline $\begin{array}{l}\text { 6. Anti-Kerala and Anti-Muslim } \\
\text { Propaganda }\end{array}$ & $\begin{array}{l}\text { Used to spread rumours and propaganda against the CPI-M } \\
\text { party and pin blame on the Muslim community. }\end{array}$ \\
\hline 7. Fact Checks & Dispelling rumours and challenging misinformation. \\
\hline $\begin{array}{l}\text { 8. Promotion of Products and } \\
\text { Accounts }\end{array}$ & $\begin{array}{l}\text { Selling elephant-themed products, promoting personal } \\
\text { accounts. }\end{array}$ \\
\hline
\end{tabular}




\section{Theme 1: Vilification of Humans}

Posts on this theme portray humans as barbarians and non-human creatures as victims. Several posts express guilt and remorse on behalf of humanity. Many posts show humans being punished by deities, animals, and 'Mother Nature' figures for betraying the elephant's trust. Some present the COVID-19 pandemic as a consequence of humans' abuse of animals.

\section{Theme 2: Non-Human Animals in Hinduism}

Several posts depict the Hindu elephant deity Ganesha, and other deities like Vishnu, Shiva, and Kali assisting the pregnant elephant or avenging its death. The elephant's death was posted about by accounts belonging to many different countries, especially China, Japan and Taiwan. We can connect this with the deity Ganesha, whose iconography travelled first to China and then to Japan. A version of Ganesha named Kangiten is a key figure in the Japanese Buddhist pantheon (Brown 1991). Around the time of the elephant's death, a cow in Himachal Pradesh died after ingesting crackers. Many posts bemoaned the lack of a massive Instagram response for the creature since cows are sacred in Hinduism.

\section{Theme 3: Glorification of Motherhood}

The elephant's pregnancy was highlighted in most posts. The visuals anthropomorphise the elephant, depicting her either with a child in the belly or talking to her baby in heaven, bemoaning the decision to trust humans. A Hindi caption on one of the posts reads, 'tumne sirf ek janwar ko nahi, ek maa ko mara hai' ['you did not just kill an animal, you killed a mother']. Motherhood is glorified in cultures across the world. In the Indian subcontinent, where several mother goddesses are worshipped, child-bearing is particularly deified (Raj 2010). Feminist scholars have contended that the societal glorification of motherly love essentialises females, equating them with their reproductive role (Neyer and Bernardi 2011).

\section{Theme 4: Diets and Animal Rights}

Many vegan and vegetarian Instagrammers took offence at meat-eaters posting about the elephant case. It was argued that they were hypocrites for criticising the elephant's 'killers', because they themselves consume the meat of other creatures. The Hindi television channel Zee News covered the elephant case extensively. The elephant was given the Hindu Goddess's name 'Vinayaki' by Zee News journalist Sudhir Choudhary, who urged viewers to follow 'Indian culture' and become vegetarians to stop the massacre of animals. Clips from Zee News were posted under \#justiceforvinayaki.

\section{Theme 5: Appropriation of the 'Black Lives Matter' Movement}

Around the time of the elephant's death, there were massive 'Black Lives Matter' protests in the United States against the police's brutal treatment of African Americans. The immediate trigger 
was the police murder of a black man, George Floyd. \#blacklivesmatter was trending on social media worldwide, and with it the seemingly innocuous \#alllivesmatter also gained popularity. 'All Lives Matter' has been used to shift the discourse from injustices faced by the black community (Yancy and Butler 2015). Many posts drew parallels between Floyd's death and the death of the elephant, and used \#blacklivesmatter and \#alllivesmatter. These posts missed the historical context of the Black Lives Matter movement, appropriating the narrative to gain visibility.

\section{Theme 6: Anti-Kerala and Anti-Muslim Propaganda}

Kerala has elected several communist governments, and the coalition currently ruling the state is led by the Communist Party of India (Marxist) (CPI-M). Several right-wing Instagram accounts attributed the elephant's death to the inhumane, irreligious nature of Kerala and its people. Posts claimed that despite being the state with the highest literacy rate in India, Keralites frequently join the Islamic State of Iraq and Syria (ISIS), work as servants in the Middle East, butcher cows, and murder elephants. Instagram posts were also used to spread rumors about Muslims being responsible for the elephant's death (Nishant 2020). Kerala's communist government was criticised for not punishing the Muslim killers.

\section{Theme 7: Promotion of Products and Pages}

The elephant's death was used by Instagrammers to demonstrate their skills and products. Various media were employed to pay homage to the elephant - sketches, paintings, photography, cartoons, digital sculptures, music performances, and dance performances. Pages used the popularity of hashtags on this incident to promote their own content. A food page created an elephant out of breakfast food, a makeup page posted elephant themed eye make-up, influencers uploaded photographs of themselves with elephants, etc. The incident was also used to sell products like elephant phone covers and soft toys.

\section{Theme 8: Fact Checks}

A few posts highlighted the facts of the case, and tried to dispel rumors and tone down the hate campaigns against specific communities or ideologies. However, these posts lacked the emotive content of other posts, and had limited engagement. 
Table 3. Selection of Instagram images from the top posts of hashtags \#keralaelephantmurder, \#justiceforelephant, and \#justiceforvinayaki.

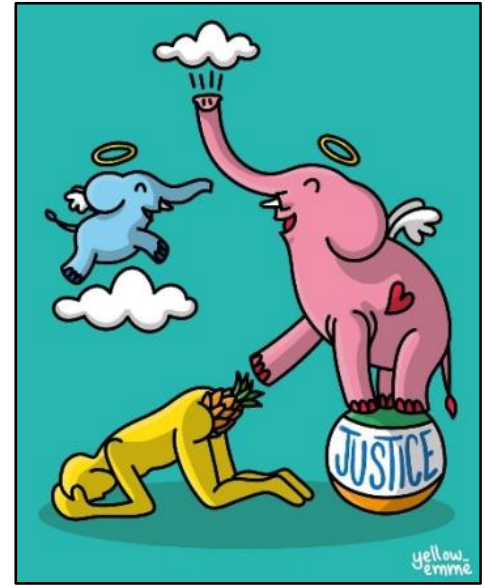

Image 3.1. Post on Theme 1, 'Vilification of Humans' by @yellow_emme

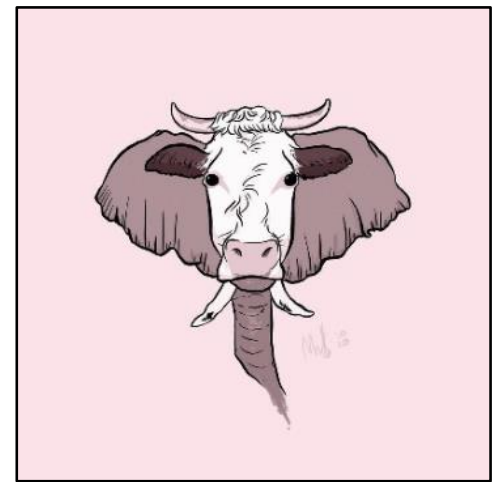

Image 3.4. Post on Theme 4, 'Diets and Animal Rights' by @max.hashi

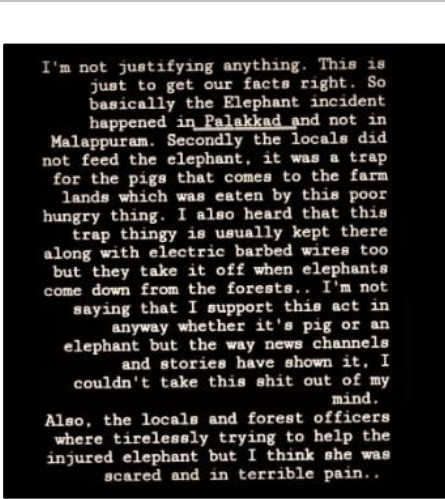

Image 3.7. Post on Theme 7, 'Fact Checks' by@being_vaidya

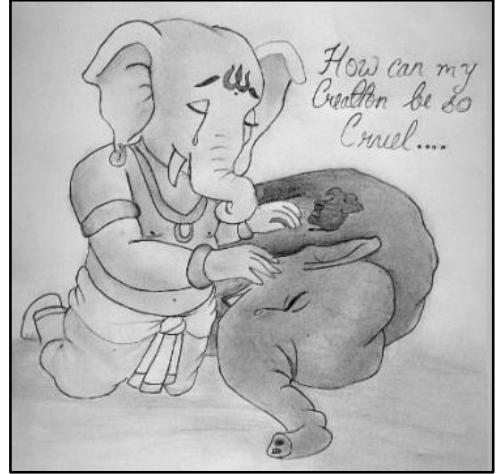

Image 3.2. Post on Theme 2, 'NonHuman Animals in Hinduism' by @artistic_aadi

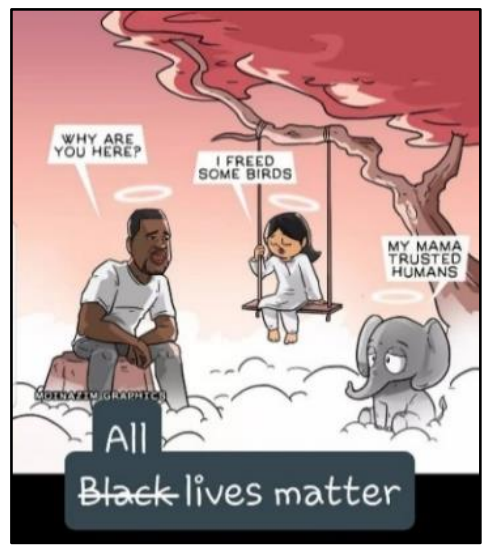

Image 3.5. Post on Theme 5,

'Appropriation of Black Lives Matter' by @shilzaghori

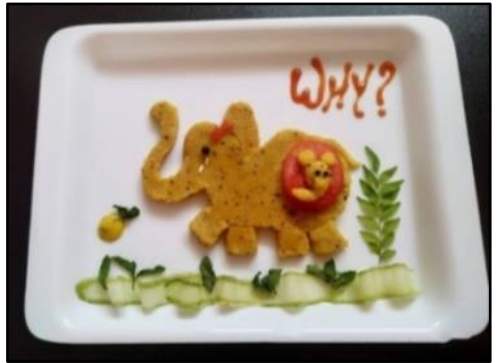

Images 3.8. Post on Theme 8

'Promotion of Products and Accounts' by @ the_culinary_cottage

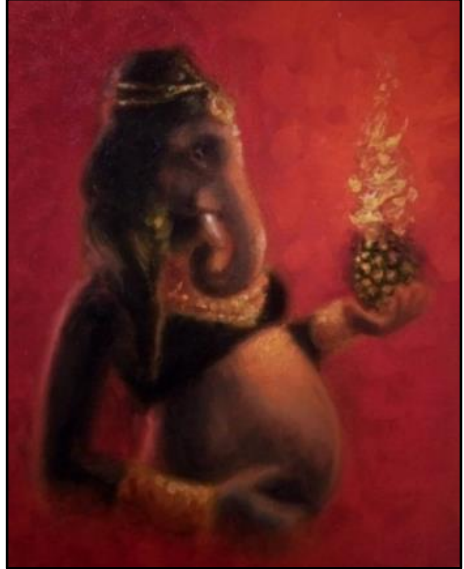

Image 3.3. Post on Theme 3,

'Glorification of Motherhood' by

@p.r.a.s.h.a.n.t.98

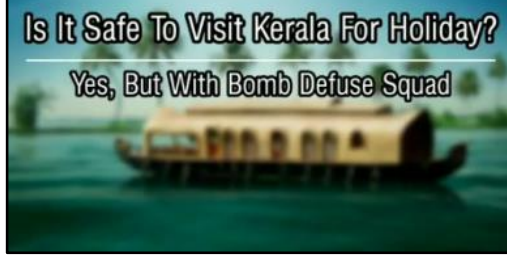

Image 3.6. Post on Theme 6, 'Anti-

Kerala and Anti-Muslim

Propaganda' by @the_fauxy 
Graph 1: Posts containing \#keralaelephantmurder, \#justiceforelephant, and \#justiceforvinayaki. Note: $\mathbf{N}=300$.

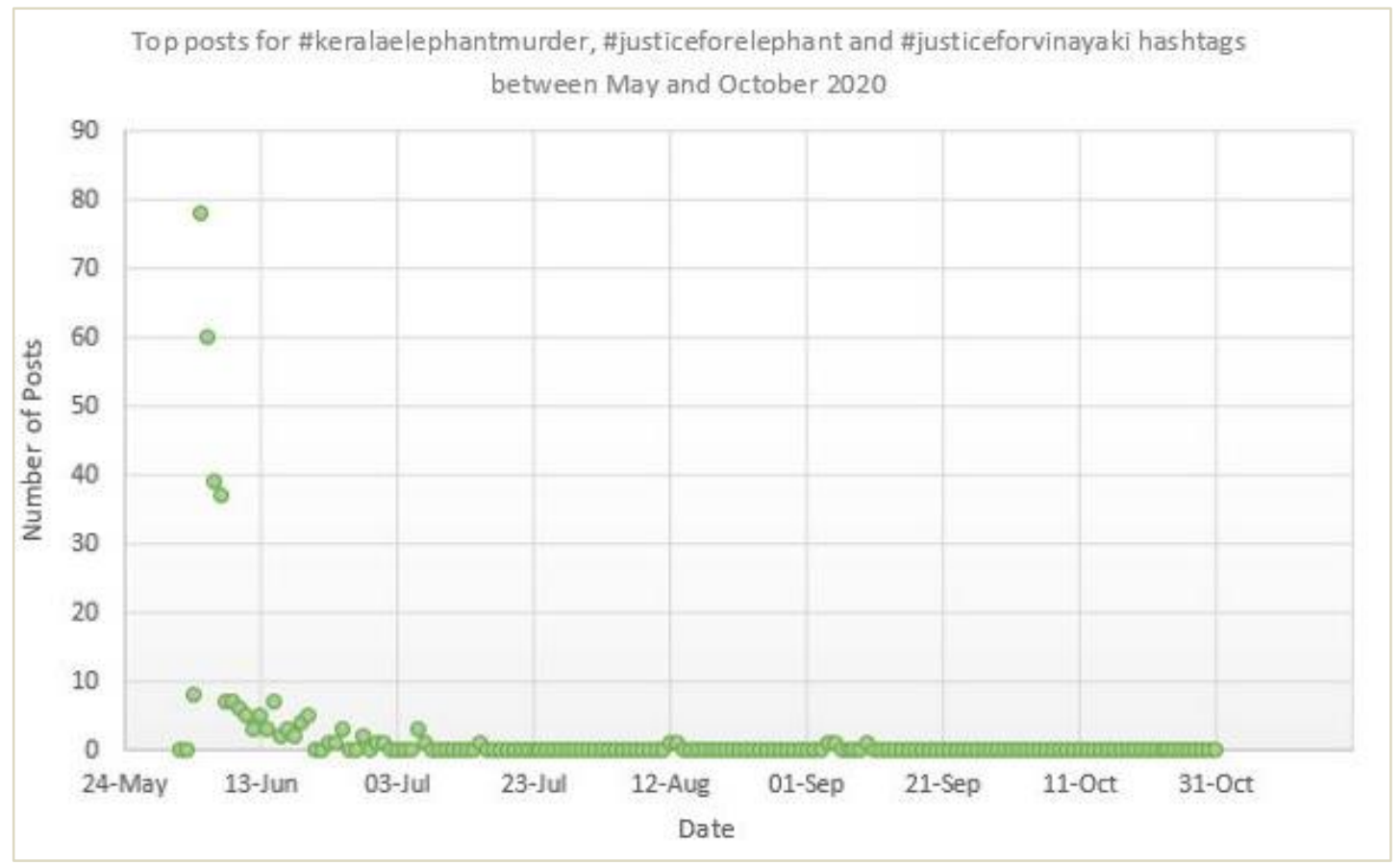

\subsubsection{Life Cycle of Case-Study 1}

The scatterplot shows an initial upsurge and then plummets downwards before resting on the $\mathrm{x}$ axis. In a brief period between 3 June and 7 June, a large number of posts on the elephant case were shared. However, from 8 June, the number of posts began to decline, and eventually died out.

\subsection{Case-Study 2: Baghjan Oil and Gas Leak}

\subsubsection{Background}

Oil India Limited (OIL) is the second largest public-sector company excavating hydrocarbons in India. OIL's Baghjan oil field is situated in Tinsukia town in Assam in northeast India. It is situated close to Dibru-Saikhowa National Park and Biosphere Reserve. On 27 May 2020, an oil well in Baghjan exploded, setting fires across nearby villages. Thousands of families were displaced, plant and animal life were devastated, and the ecosystem was further damaged by the water, air and light pollution (Raghunandan 2020). The incident became particularly controversial because the central government had recently passed the Draft Environmental Impact Assessment (EIA) Notification 2020, which is set to weaken the existing EIA system in India. Subsequently, protests and hunger strikes took place demanding compensation for the affected families (Jaiswal 2020). There were also remonstrations against the notification. 


\subsubsection{Thematic Classification}

Through our content analysis of three hundred top posts tagged \#baghjan, \#baghjanoilfield, and \#savebaghjan, we identified the seven themes discussed below. Often multiple themes overlapped in posts.

Table 4: Themes identified in Instagram posts on the Baghjan case.

\begin{tabular}{|c|c|}
\hline THEMES & OVERVIEW \\
\hline 1. Images of Devastation & $\begin{array}{l}\text { Painful visuals depicting creatures and landscapes affected by the } \\
\text { leak. }\end{array}$ \\
\hline 2. News Updates & Posts providing information and updates from Baghjan. \\
\hline $\begin{array}{l}\text { 3. Indifference of } \\
\text { Mainstream Media }\end{array}$ & $\begin{array}{l}\text { Criticism of the limited media coverage and outrage over the } \\
\text { Baghjan case. }\end{array}$ \\
\hline 4. Role of Armed Forces & $\begin{array}{l}\text { Posts appreciating the Indian army and expressing gratitude for } \\
\text { controlling the fire. }\end{array}$ \\
\hline 5. Calls for Action & $\begin{array}{l}\text { Posts used to spread awareness about the leak, gather funding for } \\
\text { affected community, and support for on-ground mobilisation. }\end{array}$ \\
\hline 6. Political Satire & $\begin{array}{l}\text { Comments on the apathy of politicians towards environmental and } \\
\text { political issues in Assam. }\end{array}$ \\
\hline 7. Baghjan and EIA 2020 & $\begin{array}{l}\text { Information and criticism of Draft EIA Notification 2020, urging } \\
\text { people to challenge it. }\end{array}$ \\
\hline
\end{tabular}

\section{Theme 1: Images of Devastation}

Several posts brought forth the devastating impacts of the oil and gas leak on humans and nonhumans alike. The first post to draw attention to the incident was a photograph of a charred Gangetic dolphin taken by tour guide Binanada Hatiborua and shared by the Guwahati chapter of the youth organisation Fridays for Future (@fridays4future.ghy). Other posts included pictures of the burning oil well, burning trees, and dying plants and animals. Photographs by Assamese photographer Diganta Rajkhowa (@digantarajkhowa) were widely reposted. Rajkhowa highlighted the human impact of the tragedy by placing Baghjan residents and firefighters in the foreground, and the fire in the background. His photograph of a local couple staring at the blazing oil well has been translated into paintings, sketches, and street art. 


\section{Theme 2: News and Updates}

Northeastern news organisations have regularly shared posts about the oil and gas leak. Their posts do not mention the human impact of the disaster or local protests; rather they provide updates on the control operation and official statements by OIL India and other government organisations.

\section{Theme 3: Indifference of Mainstream Media}

Many posts condemned Hindi and English television and print media for their lack of coverage of the Baghjan incident. Our own observations confirm that the reportage on Baghjan in print and television media was limited in the immediate aftermath of the event. Instagram became a useful medium for the dispersal of information and discussion around the issue.

\section{Theme 4: Role of Armed Forces}

Indian army fan accounts also posted about the Baghjan incident, emphasising the role played by troops in controlling the fire, and lauding their construction of a composite bridge to the oil well amid harsh weather and fumes.

\section{Theme 5: Calls for Action}

Instagram posts were used to spread awareness about the disaster and gather funds for the affected community. The Guwahati chapter of the climate-justice organisation, Fridays for Future, posted regular updates and images from Baghjan, and organised fundraisers and donation drives. Comedian Abhineet Mishra used video posts to bring the gas leak to people's attention, and also organised a fundraising campaign. Apart from gathering financial aid and amenities, Instagram was used to urge doctors and mental health professionals to provide local communities with assistance.

\section{Theme 6: Political Satire}

Instagram posts were used to comment on the apathy of politicians towards other environmental and political issues in Assam such as recurring floods, mining in the Dehang-Patkai Biodiversity Reserve, and killings and incarceration due to protests against the Citizenship (Amendment) Act. In one caricature (see Image 5.4), the former Chief Minister (CM) of Assam, Tarun Gogoi makes light of floods in Assam, commenting 'Even the America has floods!' while the current CM, Sarbananda Sonowal trivialises the Baghjan fire saying, 'Even Russia has explosions!' while pouring ghee (clarified butter) in the fire to ensure that it keeps burning. The indifference of the BJP towards environmental disasters in India was portrayed in various cartoons.

\section{Theme 7: Baghjan and EIA 2020}

The Baghjan explosion and EIA Notification 2020 are linked because limitations in the existing EIA system in India contributed to incidents like Baghjan, and the new legislation is set to dilute 
it further. Environmental pages employed Instagram's 'Live' feature to organise interactive sessions on the Baghjan case and EIA notification. Instagram was also used to invite people to webinars organised on other platforms. Artist Rohan Chakraborty, whose account (@green_humor) has gained massive popularity for environmental illustrations, posted twice about Baghjan and urged his followers to mail India's Environment Minister and Oil India protesting the EIA notification.

Table 5. Selection of images from top Instagram posts on \#baghjan, \#baghjanoilfield, and \#savebaghjan.

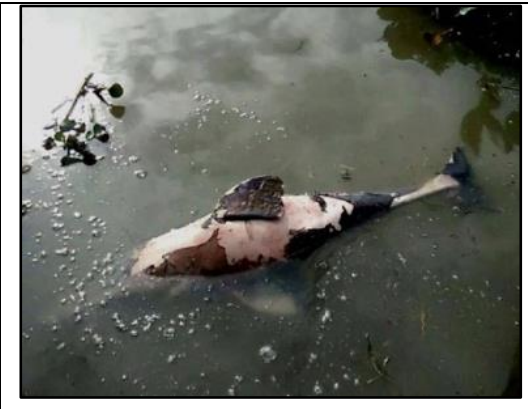

Image 5.1. Post on Theme 1, 'Images of Devastation' by@fridays4future.ghy

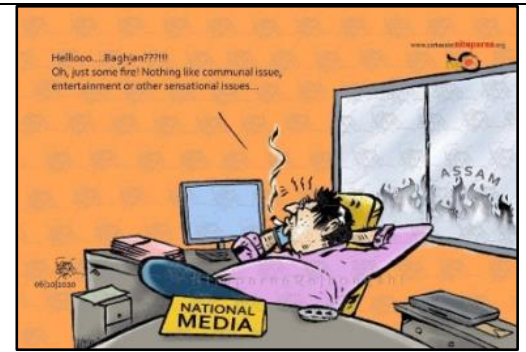

Image 5.4. Post on Theme 3,

'Indifference of Mainstream Media' by @ cartoonist_nituparna

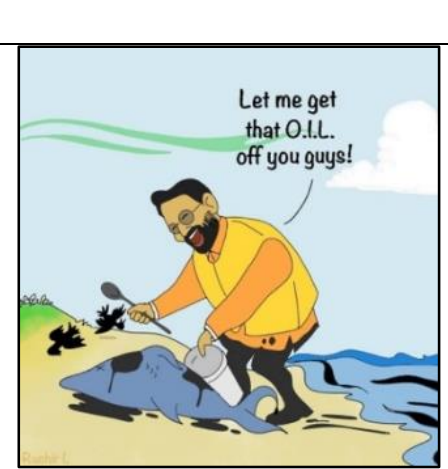

Images 5.7. Post on Theme 6, 'Political Satire' by @ ruchirlad

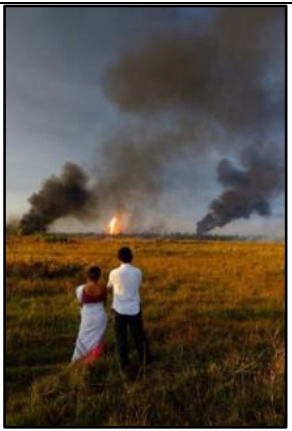

Image 5.2. Post on Theme 1, 'Images of Devastation' by@digantarajkhowa

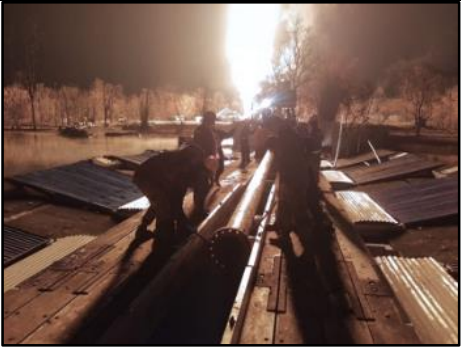

Image 5.5. Post on Theme 4, 'Role of Armed Forces' by @indian_army_fans2690

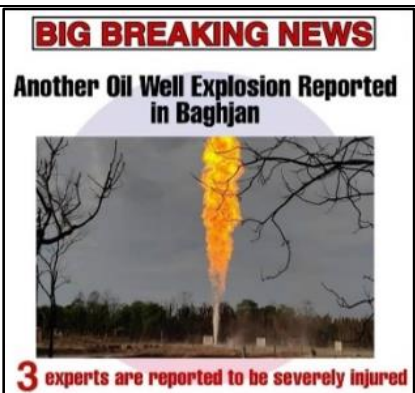

Image 5.3. Post on Theme 2, 'News and Updates' by @ hello_tezpur

Calling all mental health and overall medical health professionals to help people in Baghjan, Assam.

Since Day 1 there has been no mental health assistance provided to the people living in Baghjan.

There has been 0 to very less medical assistance provided by Oil India Limited considering women have given birth to still babies after the incident.

Image 5.6. Post on Theme 5, 'Calls for Action’ by@iawaken.in 


\subsubsection{Life Cycle of Case-Study 2 on Instagram}

Graph 2: Posts containing \#baghjan, \#baghjanoilfield, and \#savebaghjan. Note: $\mathbf{N}=\mathbf{3 0 0}$.

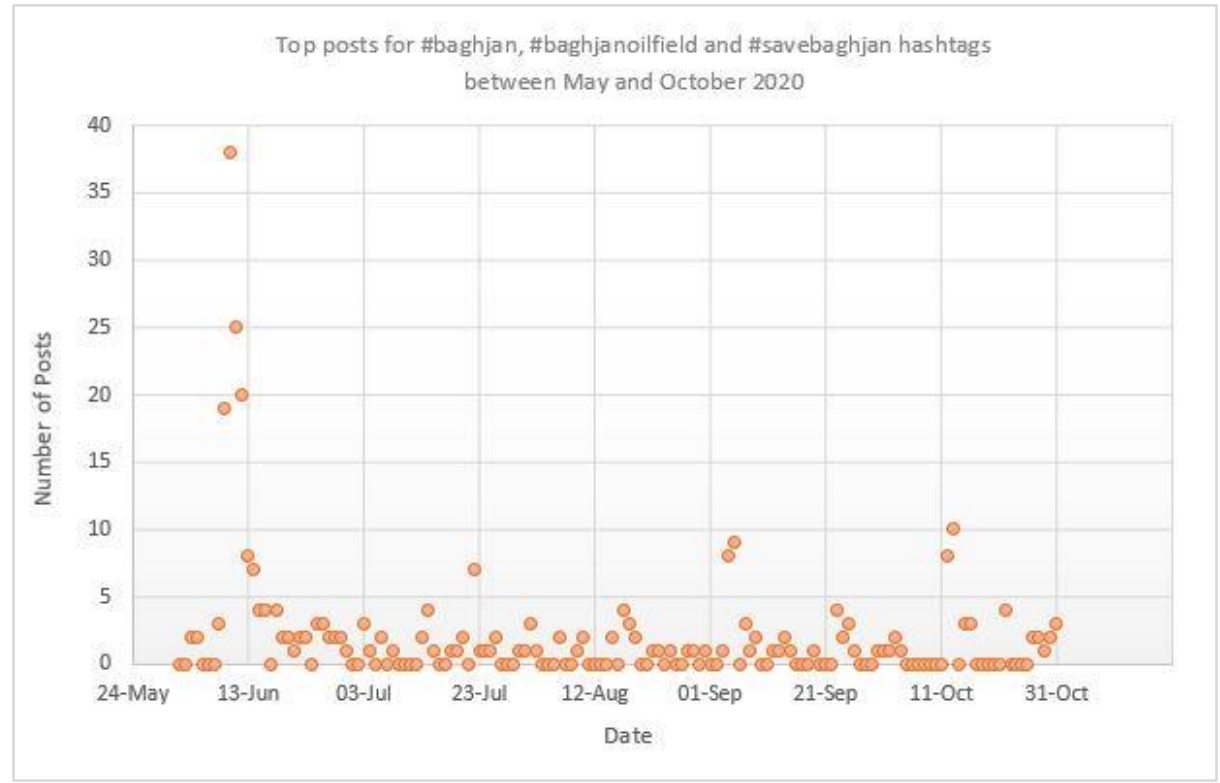

Graph 2 shows an early peak, but the points continue to bubble up in the following months. Thus, in this case while the highest number of posts were seen in the first few days after the blowout, the posts never died out. From June to October, people continued to post about the disaster. The posts hardly ever received the amount of likes and comments that posts on the elephant case did, but the engagement has remained steady.

\subsection{Competing Perceptions of Justice}

The quest for justice is at the core of both cases, but posts on Instagram reflect different perceptions of environmental justice. In the first case, some argued that people responsible for the death of the elephant should be arrested using legal provisions, others proposed societal changes such as making vegetarianism or veganism mandatory, implying changes in lifestyle in order to empathise with non-human animals. Many argued for capital punishment, lynching and torturing the 'culprits' as the only solution thereby advocating for 'instant justice' and favouring extra-legal procedure. Among the three, most posts advocated for instant justice.

In the Baghjan case, posts advised people to write to central and state governments, pushing for compensation and stricter rules for EIAs in ecologically sensitive areas. While legal solutions were proposed, there were rarely any posts which held the higher officials, bureaucrats and politicians engaged with OIL accountable. Although OIL is a public-sector company, we did not come across a single post urging the government to take definitive action against OIL's regional and national management. We see competing versions of justice here. In the case of human-wildlife conflict in 
Kerala, a large part of the audiences had made up their mind about the 'culprits' (Shaji 2020), but in the case of neglectful giant corporations harming the larger ecosystem of Baghjan, we observe no particular identification of the persons responsible and, as a result, no calls for punishments, legal or otherwise.

\section{Discussion}

In this section we look at the two case-studies together, and discuss the overlaps and contradictions in the light of theory (see Table 6 for overview).

Table 6. Comparing the two case-studies.

\begin{tabular}{|c|c|c|}
\hline THEMES & $\begin{array}{c}\text { CASE-STUDY } 1 \\
\text { (KERALA ELEPHANT DEATH) }\end{array}$ & $\begin{array}{c}\text { CASE-STUDY } 2 \\
\text { (BAGHJAN OIL LEAK) }\end{array}$ \\
\hline $\begin{array}{l}\text { 1. Relationship } \\
\text { between humans } \\
\text { and non-humans }\end{array}$ & $\begin{array}{l}\text { Human/non-human dichotomy upheld. } \\
\text { Livelihoods vilified, complexity of } \\
\text { interactions between communities and } \\
\text { creatures disregarded. }\end{array}$ & $\begin{array}{l}\text { Humans seen as part of the } \\
\text { ecosystem. Local livelihoods not seen } \\
\text { as threat to non-humans. }\end{array}$ \\
\hline $\begin{array}{l}\text { 2. Perceptions of } \\
\text { justice }\end{array}$ & $\begin{array}{l}\text { Identification and punishment of } \\
\text { 'culprits' (through torture or } \\
\text { incarceration). Conversion to } \\
\text { veganism or vegetarianism. }\end{array}$ & $\begin{array}{l}\text { Provision of financial aid to affected } \\
\text { community. Repealing EIA Notification } \\
\text { through protest. Particular persons not } \\
\text { held accountable. }\end{array}$ \\
\hline 3. Religion & $\begin{array}{l}\text { Religion was a major point of reaction. } \\
\text { Connections were drawn with deities } \\
\text { and religious texts. Blame placed on } \\
\text { Muslims for the elephant's demise. }\end{array}$ & $\begin{array}{l}\text { Posts did not have religious } \\
\text { undertones. }\end{array}$ \\
\hline 4. Timeline & $\begin{array}{l}\text { Viral event - intense uproar in initial } \\
\text { days followed by silence. }\end{array}$ & $\begin{array}{l}\text { Sustained protest - consistent posts } \\
\text { with clear information and goals. }\end{array}$ \\
\hline 5. Voices & $\begin{array}{l}\text { Scattered voices from across the } \\
\text { world. Lack of local voices and } \\
\text { leaders. Prominence of 'influencers' } \\
\text { disconnected from landscape. }\end{array}$ & $\begin{array}{l}\text { Local voices emphasised. Specific } \\
\text { pages and people most vocal. }\end{array}$ \\
\hline $\begin{array}{l}\text { 6. Appropriation } \\
\text { for sale of } \\
\text { products }\end{array}$ & $\begin{array}{l}\text { Furore harnessed for sale of elephant } \\
\text { themed products. Criticism of } \\
\text { communism. }\end{array}$ & $\begin{array}{l}\text { No attempts to promote products or } \\
\text { services. }\end{array}$ \\
\hline
\end{tabular}

The image of a dead Gangetic dolphin floating in a contaminated river with its charred skin peeling off was among the earliest photographs shared of the Baghjan leak (see Image 5.1). This image was reposted frequently, used in videos, and even translated into artwork. In the second case, it 
was another photograph, this time of a dying pregnant elephant that initiated an outburst of posts. Why did these images garner so much attention, and what does people's reaction to the suffering of these creatures tell us? To examine this phenomenon, we draw from Susan Sontag's essay, Regarding the Pain of Others (2003) which centers on wartime visuals of human pain disseminated through traditional media. Sontag argues that although people are surrounded by a blur of content in the modern world, photographs remain the most memorable since the image is the basic unit of memory. She notes that people are inordinately captivated by two kinds of images - photographs of desirable bodies, and those of bodies in pain. While it has been suggested that painful images lose their power over time, Sontag maintains that humans never become entirely habituated to them, and they continue to haunt us. Despite Sontag's framework being limited to human pain, we believe that the same haunting memorability extends to images of non-human suffering, and contributed to our case-studies gaining prominence on Instagram. This observation has important implications since it expands the boundaries of 'Others' in Sontag's thesis and confers non-human bodies with comparable status to human ones. Whether this reaction is an instinctive human response, a characteristic of particular communities and values, or the product of mainstream narratives of environmentalism is a fascinating question which falls beyond the scope of this article.

Sontag further argues that emotions elicited by painful images distract us from asking which events and whose sufferings are left out of popular discourses. In the cases discussed above, there were particular creatures to whose agony people responded with fervor. Was their prominence merely a coincidence? According to Annu Jalais (2008), certain creatures (dolphins, tigers, penguins) have become 'cosmopolitans' of the animal world, i.e., they have been transported into homes, schools, and workplaces through mass media images. Although cosmopolitan creatures are recipients of affection and protectiveness, their complexities are levelled. An unequal relationship exists between those that hold the cosmopolitan worldview, and those who must live alongside them. The elephant in the second case was a cosmopolitan creature whose death was mourned while farmers trying to safeguard their crops were vilified (see Barua 2014). The visuals of the pregnant elephant triggered emotions, but no attempts were made to understand the landscape in which the incident took place. In the Baghjan case, while the image of the dolphin increased the disaster's prominence, many posts also highlighted the human impact of the disaster. Posts depicted the entire ecosystem in the state of emergency, and did not dichotomise the issue as human versus non-human. The presence of local perspectives provided a challenge to the cosmopolitan worldview. Environmental groups like Fridays for Future (Guwahati) enabled the dissemination of voices from Baghjan and people from the region took to Instagram to share their experiences. In the elephant case, the dominant voices were scattered across the globe. The top posts included accounts of Bollywood actors (@aliaabhatt and @ anushkasharma), a Hindu temple association (@iskconkurukshetra), the State Bank of India (@sbifoundation), a Taiwanese teacher-artist (@milkhoneyplanet), a Turkey-based news service (@anews), an Egyptian Youtuber (@ayaamostafaa), and an Ecuadorian animal rescue organisation (@rescateanimalec) among others. While these 'influencers' managed to spread the elephant's story rapidly, the absence of 
local voices upheld the cosmopolitan worldview and prevented a more nuanced understanding of the incident. It is important to recognise the privilege associated with owning a social media account, and its implications for the construction of digital natures.

Another important question we address here is whether these two case-studies can be characterised as protests or simply as viral moments. Virality is defined as:

a social information flow process where many people simultaneously forward a specific information item over a short period of time, within their social networks, and where the message spreads beyond their own social networks, to different, often distant networks, resulting in a sharp acceleration in the number of people who are exposed to the message. (Nahon and Hemsley 2013, p. 16)

Virality is not only about the number of likes or views. It is about the speed at which a piece of content reaches people, and the networks it is able to permeate. The case of the elephant can be characterised as a viral phenomenon because it was short-lived and spread to networks across the world. Karine Nahon and Jeff Hemsley discussed the ephemeral nature of virality by plotting the life cycle of a viral YouTube video. Upon plotting dates on the $\mathrm{x}$-axis and number of views on the $y$-axis, the graph initially soared upward, and then plummeted just as rapidly. In the elephant case, a similar pattern was seen with the number of Instagram posts, which quickly peaked and fell. Viral content has the ability to transverse multitudes of networks, and this was true of the elephant case. On the other hand, the second case can be characterised as a sustained protest since posts on Baghjan did not die out after an initial surge, they have less emotional content, and are more focused on directing action. The protest has also expanded to include other related concerns, such as the EIA Notification 2020.

Viral social media phenomena are temporarily powerful, and this power may be converted into consumer action. In the elephant case, the influence of viral hashtags was harnessed to endorse products and pages. It was also used to make a case for veganism and vegetarianism. These dietary preferences are not innocuous and the ability to follow their strict limitations is deeply entangled with class, caste, racial and geographical privileges (see Shugart 2014; Sathyamala 2019). Not only was consumer action promoted by exploiting viral hashtags, these were also employed to spread misinformation and antagonism around communism and Islam. Further, the promotion of vegetarian diets has religio-political undertones. Yamini Narayanan (2018) has shown that perceptions of animal rights in India are influenced by casteist and speciesist beliefs. She suggests that laws related to bovines are prejudiced in favor of oppressive upper-caste Hindu notions of purity and divinity. Even though Hinduism has been regarded as a 'nature religion' due to the tradition of worshipping elements of nature, this does not necessarily translate into conservation practices. The perception of Hindus as naturalists can be seen clearly in the posts which urge Hindus to reunite with their roots of being elephant devotees and peace-loving vegetarians.

W.Lance Bennett (2012) argued that consumer action can be viewed as a personalised form of politics since individuals tend to mobilise around lifestyle values. He examined social fragmentation and personal action on digital media suggesting there is a decline in group loyalties. 
He pointed to personalised forms of political participation on digital platforms, sometimes with political organisations enabling them, sometimes with crowds using layers of social media for action. According to Bennett, the main driving forces are actions based on specific consumer styles or product, and this form of personalised politics can be more successful than other forms of protests. In our study, we focus on consumer behaviour in the light of personalised action for particular discourse on 'environmental justice'. The key question here is whether these cases were a result of coordinated consumer action or a genuine demand for environmental justice. We believe that it was actually both, and that the demand for environmental justice is not mutually exclusive of consumer action, especially in digital spaces. Any attempt to discern the complex nature of our case-studies, both situated in different geographical landscapes, would require further examination into specific economic and social-political contexts.

Let us now look at whether ideas of environmental justice on Instagram reproduce existing prejudices based on socio-economic and cultural position and promote systemic exclusion. Walker (2009a) examined the significance of spatiality and geographies in perpetuating injustices. He used the concept of 'Spaces of Misrecognition', where certain groups of people and specific places are devalued and strategically misrecognised. The people in these landscapes are blamed for their supposed misfortunes and their ecological embeddedness is insignificant for policy-makers and the state. Global financial institutions like the IMF and World Bank have played a problematic role in shaping public discourses by funding controversial development projects in the Global South (Stiglitz 2002). Hence it is likely that Instagram, which is a global platform for activists and advocacy groups, reproduces the existing discourses. The elephant case demonstrates misrecognition of spaces and through the various posts we analysed also upholds the human/nonhuman binary. A case of human-wildlife conflict in rural Kerala is viewed as a deliberate attempt by farmers to cause harm to a pregnant elephant, and instant and violent punishments were sought as justice. The elephant was not killed in an act of brutality, rather its death was the result of persisting conflict between humans and non-humans. The visuals on Instagram, however, reinforced the existing prejudices of the urban-rural divide.

In their study on the governance of environmental justice in India, Glyn Williams and Emma Mawdsley (2005) observed that the post-independence Indian state has undertaken mass displacement for development projects. Narratives of modernisation, urbanisation, and welfare politics propounded by Jawaharlal Nehru, the first Prime Minister of independent India, still shape the economic rationale in India. The unwillingness to challenge the idea of unlimited economic growth is among the core problems. The policy apparatus and public debates are designed around the conceptually weak idea of development and economic growth, leading to incorrect identification of issues in the realm of natural resource politics and eventually towards poor formulation of environmental policies. These ideas allow us to address why the 'culprits' were never singled out on Instagram posts in the case of the Baghjan oil and gas leak. As a large public corporation, OIL, the company responsible for the devastating explosion, is considered prestigious as it generates jobs and revenue. Apart from this, its location in the small Assamese town of Tinsukia contributed to the lack of coverage, exemplifying Walker's (2009b) concept of 'Spaces 
of Vulnerability and Wellbeing' in which he notes that marginalised communities have to deal with an inordinate number of environmental 'bads', further reproducing vulnerability over time and across space.

\section{Towards Conclusions}

This article illustrates the power of Instagram visuals to elicit emotions, construct virtual natures, and enable environmental protests. An important question here is whether this power translates into action beyond digital spaces. In the elephant case-study there was a lack of clear goals and leadership, but in the Baghjan case the digital uproar did facilitate aid to the affected community from both the state and individuals. OIL also provided compensation to families affected by the disaster in October 2020. However, the battle against the EIA Notification 2020 carries on. Does the lack of government response to public concerns against the new policy reflect the inadequacy of social media movements? It would be simplistic to draw this conclusion since the larger political context in present-day India must also be taken into account. The upper-caste Hindu ideology is not just a dominant discourse in Indian politics and society, it also shapes environmental debates and actions. As argued by Narayanan (2018), religious environmentalism in India promotes speciesism and layered oppressive tendencies, which not only affects the humans associated with certain animals and landscapes, but also adversely affects the overarching environmental discourse based on scientific knowledge and community-driven actions.

Looking at our case-studies, it is clear that voices on social media are divided with regard to environmental justice. In the elephant case, certain posts and comments dismissed the complexities of human-wildlife conflict and demanded punishment for locals. However, it did bring into mainstream discourse the presence of such conflicts and that perhaps these are more frequent than many imagined it them be. In the Baghjan case, most posts tacitly excused the management of OIL by not mentioning them, but the case was effective in highlighting the problems with the Draft EIA Notification 2020. Concerns on social media and its users are dynamic - that is, they do not owe permanent affiliations and loyalty to particular social or environmental movements. Therefore, expecting serious commitment by Instagrammers is not useful. As Goodman et al. (2016) maintain, users interact not only on the basis of mutual interests, but also as consumers.

Methodologically, an important limitation of this work is the absence of insights from Instagram 'Stories', which are only available for twenty-four hours after being posted. This is an important feature of the platform, and is particularly useful for protests since it allows users to speedily share urgent information. Stories may also be functioning as safe digital spaces for protestors due to their ephemerality, and thus there is an urgent need to develop research methodologies incorporating the Stories feature. Another question of who was able to enlist their opinion on Instagram and their respective class and caste background was largely unexplored. Further examination of the social capital of Instagram users, influencers and celebrities is needed. We observed people from all over the world sharing posts and stories on both incidents, and it would be a generalisation to draw premature conclusions based on only two case-studies. Such conclusions would require critical 
assessment into the political economy being shaped in the post-pandemic world. In the Indian context, thoughtful enquiries need to be conducted for deciphering the forms of Hindutva (religious nationalism) promoted by the ruling right-wing government, and their far-reaching impact on material, spiritual and cyber culture, all of which have implications beyond this study, especially in the realm of environmental justice. 


\section{Appendix A}

Image credits:

\section{Image 3.1}

Maggiolo, M. [@yellow_emme] (2020) In the end, what goes around comes around! [Instagram] 11 June. Available at: https://www.instagram.com/p/CBTRPhKgAJF/ (Accessed: 10 November 2020).

\section{Image 3.2}

Gadade, A. [@artistic_aadi] (2020) How can we be so selfish and cruel for our life, that we can't

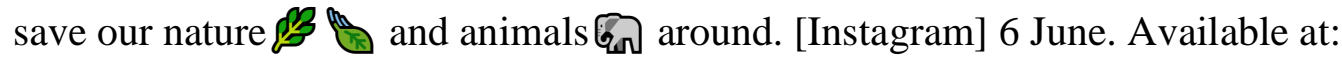
https://www.instagram.com/p/CBGi-wEJCi4/ (Accessed: 10 November 2020).

\section{Image 3.3}

Naikode, P. [@p.r.a.s.h.a.n.t.98] (2020) त्याला देवंपण देणारेही आपणच... आणी राक्षसी वृत्तीने त्याचा जिव घेणारेही आपणच... [Instagram] 4 June. Available at: https://www.instagram.com/p/CA _WDXjImN/ (Accessed: 10 November 2020).

\section{Image 3.4}

Hashi, M. [@max.hashi] (2020) Sometimes the difference is our perception. [Instagram] 7 June. Available at: https://www.instagram.com/p/CBJExarDHSq/ (Accessed: 10 November 2020).

\section{Image 3.5}

Ghori, S. [@shilzaghori] (2020) \#blacklivesmatter $0 \bigcirc \bigcirc \ldots \leftarrow \bigcirc \bigcirc \bigcirc \bigcirc \bigcirc$ \#allivesmatter. [Instagram] 6 June. Available at: https://www.instagram.com/p/CBGS8WdFvSM/ (Accessed: 10 November 2020).

\section{Image 3.6}

@ the_fauxy (2020) 5 Things To Know About Kerala. [Instagram] 4 June. Available at: https://www.instagram.com/p/CBBcPaxgYjH/ (Accessed: 10 November 2020).

\section{Image 3.7}

@ being_vaidya (2020) Don't spread hatred, anyway if a person does something extremely wrong. That doesn't mean that entire state is wrong... [Instagram] 4 June. Available at: https://www.instagram.com/p/CBAsKhwjTPa/ (Accessed: 10 November 2020).

\section{Image 3.8}

@ the_culinary_cottage (2020) She was pregnant. She was hungry. She did a mistake. She believed humans. This manmade blunder tears my heart apart. [Instagram]. 4 June. Available at: https://www.instagram.com/p/CBAaydYHw8i/ (Accessed: 10 November 2020).

\section{Image 5.1}

Fridays For Future Guwahati [@fridays4future.ghy] (2020) Binanda Hatiboruah, a birder and tour guide was the first to post images of an oil spill spreading across the Maguri wetland in 
Assam. [Instagram]. 6 June. Available at: https://www.instagram.com/p/CBGSc1XHiW8/ (Accessed: 15 November 2020).

\section{Image 5.2}

Rajkhowa, D. [@digantarajkhowa] (2020) Baghjan, Tinsukia, Assam Gas well blowout: The fire at Baghjan 5 has inundated homes and adverse damage to the flora... [Instagram]. 11 June. Available at: https://www.instagram.com/digantarajkhowa/ (Accessed: 15 November 2020).

\section{Image 5.3}

Hello Tezpur [@ hello_tezpur] (2020) Enough already. [Instagram]. 22 July. Available at: https://www.instagram.com/p/CC8M_cuHupK/ (Accessed: 15 November 2020).

\section{Image 5.4}

Rajbongshi, N. [@cartoonist_nituparna] (2020) \#NationalMedia \#BaghjanOilSpill \#Baghjan \#BaghjanFire \#SaveBaghjan \#Assam. [Instagram]. 10 June. Available at: https://www.instagram.com/p/CBQ3XsgHURg/ (Accessed: 15 November 2020).

\section{Image 5.5}

@indian_army_fans2690 (2020) NationFirst \#HarKaamDeshKeNaam \#IndianArmy bridging operations near the blowout site of \#Baghjan Oil field. [Instagram]. 26 June. Available at: https://www.instagram.com/p/CB4Z4i6JFfT/ (Accessed: 15 November 2020).

\section{Image 5.6}

@iawaken.in. (2020) \#Baghjan needs our help! Follow @fridays4future.ghy_for more Information and how to help. [Instagram]. 12 September. Available at:

https://www.instagram.com/p/CFCmN1NJ_tW/ (Accessed: 15 November 2020).

\section{Image 5.7}

Lad, R. [@ ruchirlad] (2020) Assam oil well still leaking gas one week after blowout. About 2,500 evacuated, amid fears leaking oil and gas has killed river dolphins and birds. [Instagram]. 4 June. Available at: https://www.instagram.com/p/CA_bgYID0R1/ (Accessed: 15 November 2020).

\section{Image 5.8}

Chakrawarty, R. [@green_humour] (2020) Oil India Limited and the @moefccgoi have the blood of Gangetic Dolphins, birds, fish and the Assamese people on their hands. [Instagram]. 9 June. Available at: https://www.instagram.com/p/CBOUw7Og8oZ/ (Accessed: 15 November 2020). 


\section{References}

Abidin, C., Brockington, D., Goodman, M. K., Mostafanezhad, M. and Richey, L. A. (2020)

'The Tropes of Celebrity Environmentalism', Annual Review of Environment and Resources, 45 , pp. 387-410.

Alley, K. D. (2019) 'River Goddesses, Personhood and Rights of Nature: Implications for Spiritual Ecology', Religions, 10(9).

Arendt, H. (2005) The Promise of Politics. New York: Schocken.

Arora, P. (2014) 'Usurping Public Leisure Space for Protest: Social Activism in the Digital and Material Commons', Space and Culture, 18(1), pp. 55-68.

Arora, P. (2019) 'Politics of Algorithms, Indian Citizenship, and the Colonial Legacy', in A. Punathambekar, A. and Mohan, S. (eds.), Global Digital Cultures: Perspectives from South Asia. US: University of Michigan Press, pp.37-52.

Banerjee, D. (2020) 'Fantasies of Control: The colonial character of the Modi government's actions during the pandemic', The Caravan, 30 June. Available at: https://caravanmagazine.in/perspectives/colonial-character-of-the-modi-governments-actionsduring-the-pandemic (Accessed: 25 September 2021).

Barua, M. (2014) 'Circulating Elephants: Unpacking the Geographies of a Cosmopolitan Animal', Transactions of the Institute of British Geographers, 39(4), pp. 559-573.

Bennett, W. L. (2012) 'The Personalization of Politics: Political Identity, Social Media, and Changing Patterns of Participation', The ANNALS of the American Academy of Political and Social Science, 644(1), pp. 20-39.

Bhat, P. and Chadha, K. (2020) 'Anti-media populism: Expressions of media distrust by rightwing media in India', Journal of International and Intercultural Communication, 13(2), pp. 166182.

Bourdieu, P. (1993) The Field of Cultural Production. Cambridge, UK: Polity Press.

Boy, J. D. and Uitermark, J. (2016) 'How to Study the City on Instagram', PLoS ONE, 11(6).

Brown, R. L. (ed.) (1991) Ganesh: Studies of an Asian God. New York: SUNY Press.

Brown, R. C., Bendig, E., Fischer, T., Goldwich, A. D., Baumeister, H. and Plener, P. L. (2019)

'Can acute suicidality be predicted by Instagram data? Results from qualitative and quantitative language analyses', PloS ONE, 14(9).

Büscher, B. and Igoe, J. (2013) "Prosuming" conservation? Web 2.0, nature and the intensification of value-producing labour in late capitalism', Journal of Consumer Culture, 13(3), pp. 283-305.

Büscher, B. (2016) 'Nature 2.0: Exploring and theorizing the links between new media and nature conservation', New Media \& Society, 18(5), pp. 726-743. 
Caldeira, S.P., De Ridder, S. and Van Bauwel, S. (2020) 'Between the Mundane and the Political: Women's Self-Representations on Instagram', Social Media + Society, 6(3), pp.1-14.

Caliandro, A. and Graham, J. (2020) 'Studying Instagram Beyond Selfies', Social Media + Society, 6(2), pp. 1-7.

Carpenter, J. P., Morrison, S. A., Craft, M. and Lee, M. (2020) 'How and why are educators using Instagram?', Teaching and Teacher Education, 96. Available at:

$\underline{10.1016 / j . t a t e .2020 .103149}$

Casaló, L. V., Flavián, C. and Ibáñez-Sánchez, S. (2018) 'Influencers on Instagram: Antecedents and consequences of opinion leadership', Journal of Business Research, 117, pp. 510-519.

Chaturvedi, S. (2016) I am a Troll: Inside the Secret World of the BJP's Digital Army. New Delhi: Juggernaut Books.

Clement, J. (2020) 'Instagram: distribution of global audiences 2020, by age group', Statista, 29 October. Available at: https://www.statista.com/statistics/325587/instagram-global-age-group/ (Accessed: 25 September 2021).

Cronon, W. (1996) 'The Trouble with Wilderness: Or, Getting Back to the Wrong Nature', Environmental History, 1(1), pp. 7-28.

Debord, G. (1967) The Society of the Spectacle. New York: Zone Books.

Ellerkamp, O. D. (2018) Purifying the Sacred: How Hindu Nationalism Reshapes Environmentalism in Contemporary India. Doctoral dissertation. Oberlin College.

Fischer, M. (2016) '\#Free_CeCe: the material convergence of social media activism', Feminist Media Studies, 16(5), pp. 755-771.

Freedom House (2020) Freedom on the Net 2020. Available at: https://freedomhouse.org/sites/default/files/202010/10122020_FOTN2020_Complete_Report_FINAL.pdf (Accessed: 25 September 2021).

Frison, E. and Eggermont, S. (2017) 'Browsing, posting, and liking on Instagram: The reciprocal relationships between different types of Instagram use and adolescents' depressed mood', Cyberpsychology, Behavior, and Social Networking, 20(10), pp. 603-609.

Gandhi, M. [@Manekagandhibjp] (2020) Mallapuram is known for its intense criminal activity specially with regards to animals. No action... [Twitter] 3 June. Available at: https://twitter.com/manekagandhibjp/status/1268071345327202305?lang=en (Accessed: 25 September 2021).

Gerbaudo, P. (2012) Tweets and the Streets: Social Media and Contemporary Activism. London: Pluto Press.

Gerbaudo, P. (2018) 'Social media and populism: an elective affinity?', Media, Culture \& Society, 40(5), pp. 745-753. 
Giannoulakis, S. and Tsapatsoulis, N. (2016) 'Evaluating the descriptive power of Instagram hashtags', Journal of Innovation in Digital Ecosystems, 3(2), pp.114-129.

Goodman, M. K., Littler, J., Brockington, D. and Boykoff, M. (2016) 'Spectacular environmentalisms: media, knowledge and the framing of ecological politics', Environmental Communication, 10(6), pp.677-688.

Greenberg, M. (1993) 'Proving Environmental Inequity in Siting Locally Unwanted Land Uses', Risk: Health, Safety \& Environment, 3(4), pp. 235-252.

Grossman, K. (1991) 'The Impact of Environmental Racism on the Black Community', The Crisis, 98(4), pp. 14-17.

Hebbar, N. (2020) PM Modi announces 21-day lockdown as COVID-19 toll touches 12', The Hindu, 24 March. Available at: https://www.thehindu.com/news/national/pm-announces-21-daylockdown-as-covid-19-toll-touches-10/article31156691.ece (Accessed: 25 September 2021).

Highfield, T. and Leaver, T. (2016) 'Instagrammatics and digital methods: Studying visual social media, from selfies and GIFs to memes and emoji', Communication Research and Practice, 2(1), pp. 47-62.

Human Rights Watch (2021) World Report 2021: Events of 2020. Available at: https://www.hrw.org/sites/default/files/media_2021/01/2021_hrw_world_report.pdf (Accessed: 25 September 2021).

Igoe, J. (2010) 'The spectacle of nature in the global economy of appearances: Anthropological engagements with the spectacular mediations of transnational conservation', Critique of Anthropology, 30(4), pp. 375-397.

Finley, W. (2020) 'What Makes a “Top Post” on Instagram?', Instazood, 30 July. Available at: https://instazood.com/blog/what-makes-a-top-post-on-instagram/ (Accessed: 25 September 2021).

Jaiswal, U. (2020) 'Baghjan residents join green protest', The Telegraph, 31 July. Available at: https://www.telegraphindia.com/north-east/baghjan-residents-join-green-protest/cid/1787791 (Accessed: 25 September 2021).

Jalais, A. (2008) 'Unmasking the Cosmopolitan Tiger', Nature and Culture, 3(1), pp. 25-40.

Keelery, S. (2020) 'Number of social network users in India from 2015 to 2018 with a forecast until 2023', Statista, 16 October. Available at:

https://www.statista.com/statistics/278407/number-of-social-network-users-in-india/ (Accessed: 25 September 2021).

Kent, E. (2015) 'Hinduism and Environmentalism in Modern India', in Hatcher, B.A. (ed.) Hinduism in the Modern World. New York/London: Routledge, pp. 290-308. 


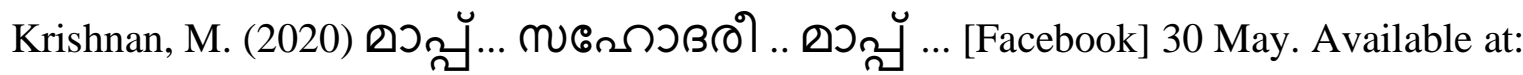
https://www.facebook.com/mohan.krishnan.1426 (Accessed: 25 September 2021).

Latour, B. (1993) We Have Never Been Modern. Cambridge, MA: Harvard University Press. Lovejoy, K. and Saxton, G. D. (2012) 'Information, Community, and Action: How Nonprofit Organizations Use Social Media', Journal of Computer-Mediated Communication, 17(3), pp. 337-353.

Macdonald, D. W., Jacobsen, K. S., Burnham, D., Johnson, P. J. and Loveridge, A. J. (2016)

'Cecil: A Moment or a Movement? Analysis of Media Coverage of the Death of a Lion, "Panthera leo", Animals, 6(5), 26.

Miller, V. (2017) 'Phatic culture and the status quo: Reconsidering the purpose of social media activism', Convergence, 23(3), pp. 251-269.

Morozov, E. (2009) 'The brave new world of slacktivism', Foreign Policy, 19 May. Available at: https://foreignpolicy.com/2009/05/19/the-brave-new-world-of-slacktivism/ (Accessed: 1 October 2020).

Nahon, K. and Hemsley, J. (2013) Going Viral. Cambridge, UK: Polity.

Narayanan, Y. (2018) 'Cow Protection as "Casteised Speciesism”: Sacralisation, Commercialisation and Politicisation', South Asia: Journal of South Asian Studies, 41(2), pp. 331-351.

Neyer, G. and Bernardi, L. (2011) 'Feminist Perspectives on Motherhood and Reproduction', Historical Social Research/Historische Sozialforschung, 36(2), pp. 162-176.

Nishant, V. (2020) 'Who Killed the Elephant in Kerala?', The Wire, 4 June. Available at: https://thewire.in/environment/who-killed-the-elephant-in-kerala (Accessed: 25 September 2021) (Accessed: 25 September 2021).

Poell, T. (2014) 'Social Media Activism and State Censorship', in Trottier, D. and Fuchs, C. (eds.) Social Media, Politics and the State: Protests, Revolutions, Riots, Crime and Policing in an Age of Facebook, Twitter and YouTube. London: Routledge, pp. 189-206.

Punathambekar, A. and Mohan, S. (2019) 'Introduction', in Punathambekar, A. and Mohan, S. (eds.) Global Digital Cultures: Perspectives from South Asia. US: University of Michigan Press, pp. 1-34.

Raghunandan, D. (2020) 'Baghjan Oil Field Fire: A Prelude to Ecological Disaster in the North East', Newsclick, 16 June. Available at: https://www.newsclick.in/Baghjan-Oil-Field-FirePrelude-Ecological-Disaster-North-East (Accessed: 25 September 2021).

Raj, M.K. (2010) Motherhood in India: Glorification Without Empowerment? New Delhi: Routledge. 
Rodrigues, U. M. and Niemann, M. (2017) 'Social Media as a Platform for Incessant Political Communication: A Case Study of Modi’s “Clean India” Campaign', International Journal of Communication, 11.

Sathyamala, C. (2019) 'Meat-eating in India: Whose food, whose politics, and whose rights?', Policy Futures in Education, 17(7), pp. 878-891.

Serafinelli, E. (2020) 'Networked Remembrance in the Time of "Insta-Memories", Social Media + Society, 6(3), pp.1-12.

Shaji, K.A. (2020) 'Elephants become collateral damage in the fight against crop-raiding boars', Mongabay, 9 June. Available at: https://india.mongabay.com/2020/06/elephants-becomecollateral-damage-in-the-fight-against-crop-raiding-boars/ (Accessed: 25 September 2021).

Sharma, N. (2020) '"Unlock1": Malls, Restaurants, Places of Worship to Reopen June 8', NDTV, 30 May. Available at: https://www.ndtv.com/india-news/lockdown-extended-till-june-30-mallsrestaurants-can-reopen-from-june-8-except-in-containment-zones-2237910 (Accessed: 25 September 2021).

Schlosberg, D. (2004) 'Reconceiving Environmental Justice: Global Movements and Political Theories', Environmental Politics, 13(3), pp. 517-540.

Schlosberg, D. (2009) Defining Environmental Justice: Theories, Movements, and Nature. Oxford: Oxford University Press.

Shirky, C. (2009) Here Comes Everybody: How Change Happens when People Come Together. London: Penguin UK.

Shroff, K. (2020) "“We are deserted”: Migrant workers forced to walk hundreds of kilometres due to lockdown', The Caravan, 26 March. Available at: https://caravanmagazine.in/news/weare-deserted-migrant-workers-forced-to-walk-hundreds-of-kilometres-due-to-lockdown (Accessed: 25 September 2021).

Shugart, H. A. (2014) 'Food Fixations: Reconfiguring Class in Contemporary US Food Discourse', Food, Culture \& Society, 17(2), pp. 261-281.

Smith, T. G. (2017) Politicizing Digital Space: Theory, the Internet, and Renewing Democracy. University of Westminster Press.

Sontag, S. (2003) Regarding the Pain of Others. New York: Farrar, Straus and Giroux.

Souza, F., de Las Casas, D., Flores, V., Youn, S., Cha, M., Quercia, D. and Almeida, V. (2015) 'Dawn of the Selfie Era: The Whos, Wheres, and Hows of Selfies on Instagram', Proceedings of the 2015 ACM Conference on Online Social Networks. Palo Alto California USA, 2-3 November 2015. New York: Association for Computing Machinery, pp. 221-231.

Stanley, A. (2009) 'Just space or spatial justice? Difference, discourse, and environmental justice', Local Environment: The International Journal of Justice and Sustainability, 14(10), pp. 999-1014. 
Stiglitz, J. E. (2002) Globalization and its Discontents (Vol. 500). New York: Norton.

'Timeline of Instagram' (2021) Wikipedia. Available at:

https://en.wikipedia.org/w/index.php?title=Timeline_of_Instagram\&oldid=1013037177

(Accessed: 25 September 2021).

Towner, T. and Muñoz, C. L. (2020) 'Instagramming Issues: Agenda Setting During the 2016 Presidential Campaign', Social Media + Society, 6(3), pp.1-13.

Udupa, S. (2016) 'Archiving as History-Making: Religious Politics of Social Media in India', Communication, Culture \& Critique, 9(2), pp. 212-230.

UNICEF (2020) Remote Learning Reachability Report. Available at: https://data.unicef.org/resources/remote-learning-reachability-factsheet/ (Accessed: 25 September 2021).

Veszelszki, Á. (2016) '\#time, \#truth, \#tradition: An image-text relationship on Instagram: Photo and hashtag', in András, B. and Ágnes, V. (eds.) In the Beginning was the Image: The Omnipresence of Pictures: Time, Truth, Tradition. Frankfurt am Main: Peter Lang, pp.139-150. Walker, G. (2009a) 'Beyond Distribution and Proximity: Exploring the Multiple Spatialities of Environmental Justice', Antipode, 41(4), pp. 614-636.

Walker, G. (2009b) 'Globalizing Environmental Justice: The Geography and Politics of Frame Contextualization and Evolution’, Global Social Policy, 9(3), pp. 355-382.

Wagner, C. N., Aguirre Alfaro, E. and Bryant, E. M. (2016) 'The relationship between Instagram selfies and body image in young adult women', First Monday, 21(9).

Williams, G. and Mawdsley, E. (2006) 'Postcolonial environmental justice: Government and governance in India', Geoforum, 37(5), pp. 660-670.

Yancy, G. and Butler, J. (2015) 'What's Wrong With All Lives Matter?', The New York Times, 12 January. Available at: https://opinionator.blogs.nytimes.com/2015/01/12/whats-wrong-withall-lives-matter/ (Accessed: 25 September 2021). 
Nivedita Tuli is an independent researcher based in Delhi. She has a bachelor's degree in Multimedia and Mass Communication from Indraprastha College, University of Delhi, and a master's in Environment and Development from the School of Human Ecology, Ambedkar University Delhi. She is currently with the Department of Forests and Wildlife, Delhi. Her research interests include political ecology, urban geography, and queer histories.

E-mail: nivedita.tuli97@gmail.com

Azam Danish is an independent researcher based in Delhi. He has a bachelor's degree in History from Jamia Millia Islamia, Delhi and a master's in Environment and Development from the School of Human Ecology, Ambedkar University, Delhi. He is interested in political ecology (particularly of marine landscapes), environmental governance, displacement and rehabilitation studies, and digital media studies.

E-mail: azamdanish13@gmail.com 